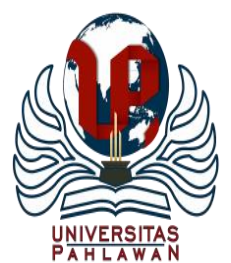

Edukatif : Jurnal Ilmu Pendidikan Volume 3 Nomor 2 Tahun 2021 Halm 505 - 513 EDUKATIF: JURNAL ILMU PENDIDIKAN

Research \& Learning in Education

https:/ledukatif.org/index.php/edukatif/index

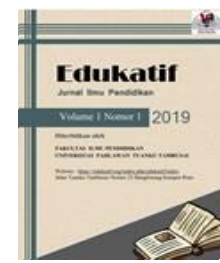

\title{
Validitas Unit Kegiatan Belajar Mandiri Untuk Meningkatkan Higher Order Thinking Skill Peserta Didik
}

\author{
Nurul Afifah ${ }^{1 凶}$, Dwikoranto $^{2}$ \\ Pendidikan Fisika, Fakultas Matematika dan Ilmu Pengetahuan Alam, Universitas Negeri Surabaya ${ }^{1,2}$ \\ E-mail : nurul.17030184102@mhs.unesa.ac.id ${ }^{1}, \underline{\text { dwikoranto@unesa.ac.id }}^{2}$
}

\begin{abstract}
Abstrak
Penerapan Kurikulum 2013 menitikberatkan proses belajar pada keaktifan serta kemandirian peserta didik dalam mengolah informasi dengan melaksanakan pembelajaran menggunakan media yang disusun secara inovatif sehingga dapat meningkatkan keahlian peserta didik untuk berpikir tingkatan tinggi dalam menuntaskan suatu permasalahan. Penelitian ini dilakukan untuk menilai validitas media Unit Kegiatan Belajar Mandiri sebagai bahan ajar untuk dapat meningkatkan Higher Order Thinking Skill pada peserta didik kelas XI materi suhu dan kalor. Metode penelitian menggunakan model 4-D melalui tahapan define, design, develop serta disseminate tetapi tanpa menerapkan disseminate karena terhalang oleh situasi pandemi covid. Validasi dilakukan pada Rencana Pelaksanaan Pembelajaran dan Unit Kegiatan Belajar Mandiri yang diujikan kepada 3 validator terdiri dari 2 dosen fisika dan satu guru fisika dengan membagian angket evaluasi penilaian. Hasil penilaian validasi Rencana Pelaksanaan Pembelajaran mendapat rata - rata skor 90,41\% dengan kriteria sangat valid serta presentase rata - rata validasi Unit Kegiatan Belajar Mandiri memperoleh skor 90,00\% dengan kategori sangat valid yang memuat kontruksi soal Higher Order Thinking Skill pada tingkatan menganalisis (C4) 41,55\%; mengevaluasi (C5) 36,17\% serta tingkatan mengkreasi (C6) 21,28\% yang menunjukkan bahwa perangkat dan media yang sudah dikembangkan tergolong dalam kategori sangat valid dan dapat diterapkan untuk meningkatkan keahlian Higher Order Thinking Skill peserta didik.
\end{abstract}

Kata Kunci: Rencana Pelaksanaan Pembelajaran, Unit Kegiatan Belajar Mandiri, dan Higher-Order Thinking Skill.

\begin{abstract}
The implementation of curriculum 2013 emphasizes the learning process on the activeness of learners in processing information by carrying out learning using innovatively arranged media to improve learners' high order thinking skills in problem solving skills. This study was conducted to assess the validity of the media Self-Learning Activity Unit as teaching material to improve Higher-Order Thinking Skills in students of grade XI on materials of temperature and heat. The method used in the research was 4-D models through define, design, develop and disseminate stages but without applying disseminate because it is hindered by the covid pandemic situation. Validation is carried out on Learning Implementation Plan and Self-Learning Activity Unit which is tested to 3 validators consisting of dividing assessment questionnaire. The results validation assessment of the Learning Implementation Plan got an average score of 90,41\% with very valid criteria and percentage of validation SelfLearning Activity Units obtained a score of 90,00\% with a very valid category containing the construction of HigherOrder Thinking Skills level of analyzing (C4) 41,55\%; evaluate (C5) 36,17\% and create (C6) 21,28\% which indicates that devices and media that have been developed fall into the category very valid and applicable to improve learners' Higher-Order Thinking Skills.
\end{abstract}

Keywords: Learning Implementation Plan, Self-Learning Activity Units, and Higher-Order Thinking Skills

Copyright (c) 2021 Nurul Afifah, Dwikoranto

$\triangle$ Corresponding author

Email : nurul.17030184102@mhs.unesa.ac.id

DOI : https://doi.org/10.31004/edukatif.v3i2.352

ISSN 2656-8063 (Media Cetak)

ISSN 2656-8071 (Media Online)

Edukatif : Jurnal Ilmu Pendidikan Vol 3 No 2 Tahun 2021 p-ISSN 2656-8063 e-ISSN 2656-8071 
DOI: https://doi.org/10.31004/edukatif.v3i2.352

\section{PENDAHULUAN}

Penerapan pembelajaran Kurikulum 2013 menitikberatkan pada pengembangan sumber daya manusia yang lebih baik serta dapat mempersiapkan generasi bangsa yang dapat bersaing pada abad ke - 21. Prinsip utama penerapan dengan memfokuskan proses pendidikan yang berpusat pada peserta didik dalam membangun serta memastikan konsep secara mandiri sehingga peserta didik dapat melakukan observasi, bernalar, bertanya serta dapat mengkomunikasikan pembelajaran yang diperoleh (Lestari, 2017). Kurikulum 2013 lebih menekankan pada keaktifan serta kemandirian peserta didik dalam mendapatkan dan mencerna informasi pengetahuan yang dicapai menggunakan pendekatan saintifik. Implementasi pendidikan dapat dilakukan dengan pengembangan informasi dan efisiensi sesuai taraf kemampuan peserta didik. Peningkatan standarisasi dapat dilakukan jika peserta didik sanggup melakukan pembelajaran di atas standar yang sudah ditetapkan berdasarkan indikator pencapaian kompetensi dan metode yang diterapkan (Maghfiroh, 2020).

Permendikbud no 158 tahun 2014 tentang pola pendidikan Sistem Kredit Semester (SKS) yang merupakan wujud penyelenggaraan pembelajaran dengan memastikan jumlah beban belajar serta mata pelajaran yang diikuti pada tiap semester untuk satuan pembelajaran sekolah menengah ataupun madrasah selaras dengan bakat, atensi serta keahlian belajar dari peserta didik (Permendikbud, 2014). Pengorganisasian pola SKS diselenggarakan melalui pembelajaran bervariasi dan pengelolaan waktu pembelajaran yang fleksibel dengan penyediaan unit - unit pendidikan utuh tiap mata pelajaran yang diimbangi dengan kecepatan belajar masing - masing peserta didik (Direktorat Pembinaan SMA, 2017).

Dengan mengembangkan Unit Kegiatan Belajar Mandiri (UKBM) sebagai bahan ajar dalam pembelajaran SKS dapat memfasilitasi peserta didik untuk mempelajari bab dalam unit pembelajaran pada suatu mata pelajaran untuk memahami kompetensi yang cocok dengan gaya serta kecepatan belajarnya. UKBM ialah satuan pelajaran kecil yang disusun secara berentetan dari bagian mudah hingga bagian yang sulit, digunakan untuk suatu pelabelan penguasaan proses belajar peserta didik pada ilmu pengetahuan serta keterampilan yang dirancang dari unit - unit ativitas belajar bersumber pada pemetaan Kompetensi Dasar. UKBM dikembangkan dari BTP (Buku Teks Pelajaran) yang mengandung beberapa proses tahapan implementasi pada peningkatan UKBM. Bentuk isi pokok UKBM memprioritaskan pemberlakuan stimulus belajar yang menguatkan tumbuhnya kemandirian serta pengalaman belajar peserta didik untuk bisa ikut serta secara aktif pada penguaaan kompetensi secara utuh lewat pendidikan yang bertaut pada peserta didik (student active) sehingga dapat memacu keahlian berfikir tingkatan tinggi (HOTS) serta keunggulan hidup di abad 21 sebagaimana diantaranya dapat berpikir kritis (critikal thinking), bertindak kreatif dan inovatif (creativity), bekerjasama (collaboration), berbicara (communication), pembudayaan dalam literasi serta penguatan pembelajaran kepribadian peserta didik dengan menerapkan komponen pengembangan karakteristik dan prinsip unit kegiatan belajar mandiri (PSMA, 2017).

Dalam kegiatan pembelajaran proses berpikir memegang suatu peranan penting untuk membangun kognisi dan pengetahuan. Suatu proses pembentukan struktur kognisi dan mental dapat efektif jika adanya kemauan yang dilakukan oleh peserta didik melalui beberapa sejumlah keterampilan berpikir. Setiap orang pada dasarnya memiliki skemata dari kerangka kognisi yang dapat mempresentasikan gagasan / ide serta persepsi baru sebagai dasar proses kegiatan berpikir. Skemata tersebut harus dapat dilatih dan dikembangkan melalui proses berpikir dari bertambahnya pengalaman belajar seseorang. Dengan membangun struktur baru atau memodifikasi struktur yang sudah ada dapat memotivasi peserta didik dalam penguasaan suatu konsep dan melatih kemampuan berpikir tingkat tinggi (Higher Order Thinking Skill). Kebanyakan sifat utama dari Higher Order Thinking Skill diantaranya tidak algoritmatik dengan tindakan yang tidak sepenuhnya dapat ditetapkan sebelumnya, bersifat kompleks dengan tidak hanya memandang dari satu sudut pandang dan memiliki banyak alternatif penyelesaian. Menuntut pengetahuan diri peserta didik dalam kegiatan proses 
berpikir dengan berbagai pertimbangan dan interpretasi yang banyak melibatkan kriteria sehingga dapat melahirkan pemaknaan baru yang lebih tinggi dalam melatih mental yang sungguh - sungguh untuk dapat melakukan elaborasi dalam memutuskan suatu permasalahan (Arends, 2008).

Unsur Higher Order Thinking Skill harus dilibatkan dalam dalam UKBM untuk dapat melatih keahlian berpikir tingkatan tinggi dengan ranah kognitif menganalisis (C4), mengevaluasi (C5) serta mencipta (C6) sehingga peserta didik bisa lebih aktif untuk berpikir dan berpendapat secara kritis, kreatif dan analitis terhadap informasi serta data yang diperoleh dalam memecahkan suatu masalah (Barratt, 2014). Penerapan HOTS pada peserta didik melibatkan secara langsung proses membongkar bahan kompleks menjadi bagian kecil yang lebih signifikan, dapat menemukan hubungan - hubungan, mampu memadupadankan informasi baru yang diperoleh secara inovatif dan kreatif dalam suatu konteks tertentu, serta dapat menggunakan dan mengkombinasikan semua tahapan level dalam mengevaluasi atau membuat suatu keputusan. Proses berpikir tidak dapat terhadi secara spontan dan harus dibangkitkan oleh masalah - masalah atau dengan pertanyaanpertanyaan dari beberapa kekacauan, kebingungan dan masalah yang ditemukan (Nugroho, 2018).

Kelayakan suatu UKBM merupakan penilaian yang digunakan sebagai parameter bahwa media ini layak diterapkan sebagai alternatif media pembelajaran. Validasi dapat dilakukan melalui proses membuat, memperbaiki dan mengembangkan media berdasarkan prosedur pengembangan suatu media yang telah melalui tahapan validasi. Suatu media divalidasi dapat ditinjau dari segi kualitasi isi, kontruksi bentuk soal, penilaian instrumen dan lembar validasi yang merujuk para ahli materi dan pembelajaran yang diterapkan, serta ahli media. Validasi bentuk isi menunjukkan kebenaran dari suatu konsep serta kesesuaian suatu materi yang digunakan dalam media dengan tujuan dan indikator pembelajaran. Sedangkan untuk valiadasi kontruk dapat meliputi aspek ke IPA -an untuk melatih proses keterampilan sains dengan mengamati dan mengklasifikasi serta melakukan kegiatan ilmiah pada media yang diterapkan, kesesuaian dengan karakteristik peserta didik, bersifat membimbing, persyaratan, rintangan, strategi, memberikan umpan balik, tampilan sebagai media pembelajaran serta kualitas bahasa yang dipergunakan (McKenney \& Reeves, 2014).

Materi fisika yang diterapkan pada perangkat media UKBM untuk menumbuhkan Higher Order Thinking Skill dalam penilaian ini menggunakan materi suhu dan kalor yang terdapat pada pembelajaran SMA kelas XI. Penelitian yang dilakukan pada SMAN 1 Tuban, peserta didik banyak mengalami kesulitan dalam penguasaan konsep fisika terlebih lagi pada materi suhu serta kalor yang diajarkan pada kelas XI (Surosos, 2016). Perihal ini bersesuaian dengan kompetensi dasar 3.5 yang mewajibkan peserta didik untuk bisa menganalisis pengaruh kalor serta perpindahan kalor yang meliputi ciri atau karakteristik termal suatu bahan, kapasitas dan konduktivitas kalor pada kehidupan sehari - hari (Permendikbud, 2016).

Penelitian ini dilakukan untuk dapat memfasilitasi peserta didik pada suatu media pembelajaran dalam meningkatkan keahlian berpikir tingkatan tinggi pada materi suhu dan kalor dengan menggunakan kontruksi bentuk soal HOTS. Faktor tersebut yang melatarbelakangi diadakannya riset dengan judul "Validitas Unit Kegiatan Belajar Mandiri untuk meningkatkan Higher Order Thinking Skill kelas XI". Dengan harapan bisa memudahkan peserta didik dalam mengenal serta melatih menyelesaikan suatu permasalahan dalam bidang sains pada kehidupan sehari-hari dengan konsep materi suhu dan kalor, menggunakan perangkat pembelajaran yang valid atau layak digunakan. Konsep materi tersebut disusun secara beruntun dari yang gampang sampai bagian sukar sehingga dapat lebih bisa dipahami serta dimengerti oleh peserta didik sesuai dengan karateritik dari Unit Kegiatan Belajar Mandiri. Riset ini digunakan untuk memfasilitasi pengejar ataupun guru dalam menggunakan serta memilah media pendidikan yang tepat sebagai sarana pembelajaran baru untuk terus berinovasi dalam menciptakan ide-ide baru untuk mengembangkan media dan fitur pembelajara sesuai dengan pola pendidikan yang diterapkan disekolah. Dapat memberikan informasi bentuk valid dari UKBM sehingga menjadi pengetahuan serta pengalaman baru dalam menghasilkan media pembelajaran UKBM berbasis Higher Order Thinking Skill. Masih belum terdapat riset yang menguak UKBM selaku sarana meningkatkan 
keahlian Higher Order Thinking Skill pada pembelajaran fisika materi suhu dan kalor sehingga bisa dijadikan bahan referensi sekolah yang belum menerapkan pola pembelajaran SKS untuk memperbaiki kualitas pendidikan dalam meningkatkan mutu sekolah.

\section{METODE PENELITIAN}

Rancangan dan pendekatan yang dilakukan pada Unit Kegiatan Belajar Mandiri ini mengembangkan model 4-D yang mencakup 4 tahapan ialah pendefinisian (define), perancangan (design), pengembangan (develop) serta penyebaran (disseminate) yang telah dikembangkan oleh beberapa ahli seperti S. Thiagarajan, dkk pada tahun 1976. Tetapi pada penelitian ini, hanya saja dilakukan sampai tingkatan develop tanpa menerapkan disseminate dikarenakan terhalang oleh situasi pandemi Covid-19 saat ini yang telah melanda dunia. Riset ini diuji cobakan di Jurusan Fisika, Fakultas Matematika dan Ilmu Pengetahuan Alam Universitas Negeri Surabaya pada bulan Februari sampai Maret 2021. Metode pengumpulan data yang dicoba dengan menggunakan teknik survei, memakai metode validasi melalui pemberian angket penilaian untuk menguji kelayakan fitur pendidikan yang dilakukan oleh tiga validator dari pakar materi, media serta pengembang strategi pendidikan yang melibatkan dari 2 dosen fisika serta satu guru fisika dari SMA Labschool UNESA yang telah menerapkan pola SKS pada proses pembelajarannya dan menggunakan UKBM sebagai media bahan aja. Fitur pendidikan yang digunakan pada riset ini meliputi Rencana Pelaksanaan Pembelajaran (RPP) 1 lembar serta Unit Kegiatan Belajar Mandiri (UKBM) dengan menggunakan instrumen berupa angket lembar validasi penilaian. Data yang didapat berupa skor dari setiap kriteria indikator yang diterapkan. Teknik analisis validasi ahli menggunakan nilai rata - rata dari skor secara deskriptif yang diberikan oleh masing masing validator. Parameter rata - rata menggunakan skala Rating Scale yang dapat diimplementasikan sesuai pada kriteria berikut dalam tabel 1 .

\section{Tabel 1}

Parameter Skor Penilaian Validasi

\begin{tabular}{|c|c|}
\hline Skor & Kriteria \\
\hline 4 & Sangat Baik \\
\hline 3 & Baik \\
\hline 2 & Cukup Baik \\
\hline 1 & Kurang Baik \\
\hline
\end{tabular}

(Riduwan, 2015)

Perangkat media pembelajaran dapat dinyatakan layak dari segi validasi apabila skor rata - rata nilai lebih dari ataupun sama dengan 3 (Itsnawati et al., 2019). Hasil dari nilai validasi yang telah didapat kemudian diimplementasikan menggunakan rumus berikut :

$$
\text { Skor Validasi }(\%)=\frac{\text { Jumlah Skor Total }}{\text { Jumlah Skor Maksimum }} \times 100 \%
$$

Hasil niali skor persentase yang didapat dari riset diinterpretasikan dalam wujud kriteria pada tabel sebagai berikut :

Tabel 2

Kriteria Interpretasi Skor

\begin{tabular}{|c|c|}
\hline Skor (\%) & Kriteria \\
\hline $85-100$ & Sangat Valid \\
\hline $70-84,9$ & Valid \\
\hline $55-69,9$ & Cukup Valid \\
\hline $40-54,9$ & Kurang Valid \\
\hline $0-39,9$ & Tidak Valid \\
\hline
\end{tabular}

(Riduwan, 2015) 
Media Unit Kegiatan Belajar Mandiri dinyatakan valid apabila skor rata - rata memperoleh nilai lebih dari ataupun sama dengan $70 \%$.

\section{HASIL DAN PEMBAHASAN PENELITIAN}

Produk dari penelitian dan pengembangan ini menghasilkan suatu media perangkat berupa Unit Kegiatan Belajar Mandiri untuk meningkatkan serta melatih Higher Order Thinking Skills peserta didik. Menurut Widana tahun 2017 HOTS dapat dijadikan sebagai suatu instrumen pengukuran sejauh mana keahlian berpikir tingkatan tinggi peserta didik. Subjek yang dipelajari pada UKBM merupakan materi suhu dan kalor, serta penerapannya dalam kehidupan tiap hari yang diperoleh pada pembelajaran semester ganjil kelas XI yang dimuat dalam kurikulum 2013 revisi (Widana, 2017).

Sementara itu, pada pengembangan UKBM disusun terlebih dulu Rencana Pelaksanaan Pembelajaran (RPP) selaku pedoman aktivitas dalam belajar mengajar. RPP 1 lembar digunakan sebagai lembar kegiatan yang lebih menekankan pada pendekatan scientific approach yang menerapkan model pendidikan Problem Based Learning (PBL). Sinta PBL dimulai dengan kegiatan orientasi peserta didik dilakukan dengan mengamati (literasi) melalui stimulus dengan menampilkan fenomena temperatur dan kalor yang selaras kehidupan tiap hari (Trianto, 2009). Mengorganisasikan peserta didik dalam mengidentifikasi sebanyak mungkin persoalan dan pertanyaan dalam mengembangkan rasa ingin tahu serta perilaku kritis peserta didik. Membimbing peserta didik dalam penyelidikan individu dan kelompok untuk mengumpulkan data serta menalar melalui eksperimen virtual menggunakan media Phet. Meningkatkan serta menyajikan hasil karya melalui mempresentasikan ataupun mempublis dalam suatu forum media tertentu. Kemudian menganalisis serta mengevaluasi proses pemecahan permasalahan dengan menarik kesimpulan tentang piont - piont penting dalam kegiatan pembelajaran (Arends, 2008).

Hasil dari penilaian validasi RPP pada kelengkapan dan keterkaitan tujuan pembelajaran mendapat persentase skor rata - rata $88,44 \%$ pada 5 aspek kriteria evaluasi, pada kesesuaian pemilihan serta pengorganisasian materi pembelajaran memperoleh nilai persentase skor rata - rata $94,44 \%$ pada 3 aspek evaluasi, sintaks kegiatan pembelajaran memperoleh nilai rata - rata kelayakan sebesar 88,87\% dari 6 aspek kriteria penilaian, pada pembagian fase waktu yang diterapkan memperoleh nilai rata - rata 87,50\% pada 2 aspek penilaian serta penilaian dari 2 aspek metode dan penyajian media memperoleh nilai persentase skor rata - rata 91,67\%. Bersumber 20 aspek evaluasi uji kelayakan RPP didapatkan nilai persentase keseluruhan 90,41\% dengan kategori sangat valid (Akbar, 2013). Hasil dari validasi rencana pendidikan yang disusun dalam RPP memenuhi kriteria yang sangat valid dari penjabaran kompetensi dasar, tujuan pembelajaran, penyusunan kegiatan belajar dan instrumen penilaian yang diterapkan sehingga bisa diaplikasikan dalam pendidikan fisika di kelas jenjang SMA.

Penelitian yang dilakukan oleh Rizki A. Maghfiroh pada tahun 2020 tentang Unit Kegiatan Belajar Mandiri yang dapat dimanfaatkan sebagai media atau bahan ajar dalam mengasah kemandirian dan keterampilan berpikir kritis sesuai dengan proses pembelajaran, diskusi kelas, pemberian perlakuan sccaffolding oleh guru mapel dan melatih mengerjakan soal - soal HOTS pada peserta didik (Maghfiroh, 2020). Prinsip penyusunan UKBM mengutamakan ketuntasan belajar secara individual melalui proses pembelajaran secara interaktif sehingga dapat menumbuhkan perilaku, pengetahuan dan keterampilan untuk dapat mengembangkan kemampuan peserta didik saat berpikir tingkat tinggi dalam mengolah informasi yang diperoleh. Unit Kegiatan Belajar Mandiri (UKBM) dirancang berlandaskan Kompetensi Dasar (KD) untuk dipergunakan pada pembelajaran individu maupun kelompok serta dapat diterapkan saat luring dan daring. Soal - soal yang disusun dalam UKBM harus dapat melatih peserta didik agar dapat berpikir tingkat tinggi (Higher Order Thinking Skills) yang bersifat komunikatif dan berbasis kegiatan. Tiap UKBM harus 
510 Validitas Unit Kegiatan Belajar Mandiri Untuk Meningkatkan Higher Order Thinking Skill Peserta Didik - Nurul Afifah, Dwikoranto

DOI: https://doi.org/10.31004/edukatif.v3i2.352

dituntaskan dengan adanya evaluasi penilaian tes formatif sebagai suatu indikator penguasaan konsep (Kemendikbud, 2017). Pengusunan kriteria penilaian validasi perangkat berdasarkan pada karakteristik Unit Kegiatan Belajar Mandiri yang disusun dalam tabel 3 berikut ini.

Tabel 3

Data Dari Hasil Validasi UKBM

\begin{tabular}{|c|c|c|c|}
\hline No. & Bagian Yang Dinilai & $\begin{array}{l}\text { Validasi } \\
(\%)\end{array}$ & Kriteria \\
\hline 1. & Berdasarkan Kompetensi Dasar (KD) & 100 & Sangat Valid \\
\hline 2. & Memuat tujuan pembelajaran untuk mencapai KD & 100 & Sangat Valid \\
\hline 3. & $\begin{array}{l}\text { Berkelanjutan / pengembangan terhadap penguasaan Buku Teks } \\
\text { Pembelajaran (BTP) }\end{array}$ & 83,33 & Sangat Valid \\
\hline 4. & $\begin{array}{l}\text { Dapat mengukur ketuntasan / pencapaian kompetensi belajar secara } \\
\text { individual sesuai dengan tingkat kecepatan belajar peserta didik }\end{array}$ & 83,33 & Sangat Valid \\
\hline 5. & $\begin{array}{l}\text { Bentuk kegiatan pembelajaran berpusat pada peserta didik (students } \\
\text { active) dengan menggunakan model / metode pembelajaran dengan } \\
\text { pendekatan saintifik (berbasis pada proses keilmuan) }\end{array}$ & 100 & Sangat Valid \\
\hline 6. & $\begin{array}{l}\text { Memanfaatkan teknologi pembelajaran dengan konsep dan prinsip } \\
\text { Techno Pedagogical Content Knowledge (TPACK) }\end{array}$ & 83,33 & Sangat Valid \\
\hline 7. & $\begin{array}{l}\text { UKBM memfasilitasi peserta didik untuk melatih keterampilan berpikir } \\
\text { kritis, bertindak kreatif, dapat bekerjasama dan berkomunikasi dengan } \\
\text { baik (4C) }\end{array}$ & 83,33 & Sangat Valid \\
\hline 8. & $\begin{array}{l}\text { UKBM memfasilitasi peserta didik untuk dapat menumbuhkan } \\
\text { keterampilan berpikir tingkat tinggi (Higher Order Thinking Skill) }\end{array}$ & 83,33 & Sangat Valid \\
\hline 9. & $\begin{array}{l}\text { Pertanyaan yang diterapkan pada tingkat berpikir analisis (C4), evaluasi } \\
\text { (C5) dan kreasi (C6) }\end{array}$ & 83,33 & Sangat Valid \\
\hline 10. & $\begin{array}{l}\text { Materi dalam UKBM dapat mengembangkan peserta didik untuk } \\
\text { mengaktualisasikan pengalaman dan potensi yang dimiliki }\end{array}$ & 91,67 & Sangat Valid \\
\hline 11. & $\begin{array}{l}\text { Penyajian dalam UKBM disusun secara menarik, dinamis, merangsang } \\
\text { semangat belajar, mengispirasi sekaligus dapat menyakinkan peserta } \\
\text { didik bahwa kompetensi yang sedang dipelajari dapat dikuasai dengan } \\
\text { baik }\end{array}$ & 83,33 & Sangat Valid \\
\hline 12. & $\begin{array}{l}\text { Proses belajar dan pembelajaran berlangsung secara interaktif yang } \\
\text { mengorganisasikan pengalaman belajar untuk membangun sikap, } \\
\text { pengetahuan dan keterampilan serta karakter melalui tranformasi } \\
\text { pengalam belajar melalui pembelajaran tatap muka atau online, } \\
\text { terstruktur dan mandiri }\end{array}$ & 83,33 & Sangat Valid \\
\hline 13. & $\begin{array}{l}\text { Materi dalam UKBM disusun secara sistematis dari yang mudah hingga } \\
\text { ke bagian sukar }\end{array}$ & 100 & Sangat Valid \\
\hline 14. & $\begin{array}{l}\text { Penyajian gambar dalam UKBM untuk membantu pemahanan konsep } \\
\text { dan materi }\end{array}$ & 91,67 & Sangat Valid \\
\hline 15. & Kesesuaian tampilan gambar yang disajikan & 91,67 & Sangat Valid \\
\hline 16. & Materi yang disajikan sesuai dengan konsep kehidupan sehri - hari & 91,67 & Sangat Valid \\
\hline 17. & Menggunakan kaidah bahasa Indonesia yang benar dan baik & 91,67 & Sangat Valid \\
\hline 18. & $\begin{array}{l}\begin{array}{l}\text { Ketepatan struktur kalimat yang mudah dipahami dan tidak } \\
\text { menimbulkan interpretasi }\end{array} \\
\end{array}$ & 83,33 & Sangat Valid \\
\hline 19. & Kejelasan dalam memberikan petunjuk dan arahan & 91,67 & Sangat Valid \\
\hline 20. & Ketepatan dalam penggunaan bahasa istilah & 100 & \\
\hline & Jumlah & 90,00 & Sangat Valid \\
\hline
\end{tabular}

Pada penilaian validasi UKBM yang diujikan pada 2 dosen fisika serta satu guru fisika SMA memperoleh persentase rata - rata dari total aspek penilaian sejumlah $90,00 \%$ tergolong dalam kriteria yang 
sangat valid (Akbar, 2013). Berdasarkan hal tersebut bahwa UKBM ini layak dimanfaatkan sebagai salah satu media bahan ajar dalam pendidikan mandiri peserta didik kelas XI pada modul suhu serta kalor. Pada masing masing aspek yang dinilai, dapat dijabarkan bahwa kelayakan penyajian, kelayakan bahasa, kelayakan isi dan karakteristik UKBM dapat melatih peserta didik untuk dapat menghubungkan, memanipulasi serta mentranformasikan pengetahuan dan keahlian yang dimiliki untuk dapat berpikir kritis serta kreatif dalam upaya meningkatkan kecakapan berpikir tingkat tinggi dalam menuntaskan suatu permasalahan (Widyastuti, 2015).

Ditinjau dari 47 kontruksi bentuk soal yang digunakan, 20 soal diantaranya termasuk dalam kategori berpikir logis dan kritis dengan dapat mengidentifikasi komponen - komponen dari informasi serta ide yang diperoleh untuk membangun hubungan antar elemen serta dapat mengkreasi ide / gagasan menggunakan bahasa sendiri sebagai ranah kognitif menganalisis (C4) (Bloom et al., 1956). Pada 17 soal dari beberapa kegiatan di UKBM mengharuskan peserta didik untuk dapat menilai data dan hasil eksperimen yang diperoleh kemudian dapat mengambil kesimpulan yang tepat dapat dikategorikan dalam ranah kognitif mengevaluasi (C5) (Anderson et al., 2001). Sedangkan pada 10 soal tes memuat pokok materi untuk dapat memadupadankan unsur - unsur menjadi suatu wujud baru yang utuh serta kongkret melalui perpaduan mengkreasi berbagai eleme untuk menghasilkan suatu karya yang orisinil serta mengarahkan peserta didik agar berpikir reflektif dan kreatif yang termasuk dalam ranah kognitif mencipta atau mengkreasi (C6) (Nugroho, 2018).

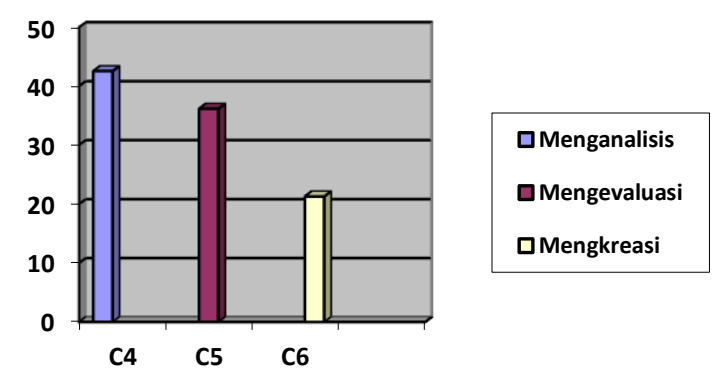

\section{Grafik 1. Gafik Persentase Soal HOTS Pada UKBM}

Berdasarkan grafik 1 data perolehan rata - rata untuk tingkatan soal HOTS yang disusun pada UKBM memperoleh persentase $42,55 \%$ pada ranah kognitif menganalisis (C4), memuat $37,17 \%$ soal dalam bentuk ranah kognitif mengevaluasi (C5) dan pada 21,28\% kontruksi soal melatih peserta didik untuk dapat mencipta atau mengkreasi (C6). Kontruksi sola yag disusun dalam UKBM mencakup 4 dimensi pengetahuan ialah pengetahuan faktual, konseptual, prosedural serta metakognitif. Pengetahuan faktual dapat mencakup suatu konsep dasar yang diimplementasikan pada keadaan atau kearifan lokal daerah pada kehidupan sehari - hari. Pengetahuan faktual dapat dihubung - hubungkan untuk membentuk makna yang lebih luas dalam menjelaskan sesuatu dapat memperkuat konsep pemahaman peserta didik. Pada UKBM peserta didik diajak untuk melakukan praktikum yang disusun secara prosedural menggunakan media Phet secara online. Penguasaan strategi dalam mengkontruksi skema pada proses belajar peserta didik untuk menimbulkan ide ataupun gagasan baru dalam membangun pengetahuan metakognitif peserta didik.

Tahapan penyusunan kontruksi soal tersebut disusun dari bagian yang gampang sampai ke bagian sukar supaya bisa meningkatkan kemampuan Higher Order Thinking Skill peserta didik saat menyelesaikan masalah dengan pengembangan kualitas instrumen soal dalam mengukur pencapaian kompetensi pemahaman konsep peserta didik mengenai kompetensi dasar dalam mencapai ketuntasan belajar (Widana, 2017).

Hasil penelitian dari pembuatan media perangkat UKBM dapat dipergunakan sebagai suatu acuan bagi penelitian lain yang berkaitan sehingga bisa memberikan informasi bentuk valid dari bahan ajar Unit Kegiatan 
512 Validitas Unit Kegiatan Belajar Mandiri Untuk Meningkatkan Higher Order Thinking Skill Peserta Didik - Nurul Afifah, Dwikoranto

DOI: https://doi.org/10.31004/edukatif.v3i2.352

Belajar Mandiri yang telah dikembangkan. Dengan adanya UKBM dapat memberikan warna dan suasana baru dalam proses pembelajaran peserta didik untuk menumbuhkan keahlian berpikir tingkat tinggi saat menyelesaikan suatu masalah. Para pengajar dapat memilih media pembelajaran yang tepat serta bisa terus berinovasi dengan perkembangan jaman untuk menciptakan ide baru sebagai pemanfaatan media pembelajaran yang beragam dan meningkatkan profesionalisme saat mengajar dalam memperbaiki kualitas mutu pendidikan di sekolah. Riset ini membutuhkan penelitian lanjutan dalam menguji efisiensi serta daya guna efektivitas UKBM pada pembelajaran peserta didik dan diperlukan pengembangan pada materi ajar yang lain dengan fokus aktivias yang lebih luas.

\section{KESIMPULAN}

Unit Kegiatan Belajar Mandiri berbasis Higher Order Thingking Skill pada materi suhu dan kalor yang telah disusun memenuhi kategori sangat layak dengan persentase skor rata - rata keseluruhan sejumlah 90,00\% dengan standard sangat valid. Kesesuaian Rencana Pembelajaran 1 lembar yang digunakan dari 20 aspek penilaian mendapat persentase skor rata - rata 90,41\% dengan parameter yang sangat valid. Menerapkan kontruksi soal Higher Order Thinking Skill pada tingkatan menganalisis (C4) sebanyak 41,55\%; pada 36,17\% memuat soal dalam bentuk mengevaluasi (C5) dan 21,28\% melatih peserta didik dalam mengkreasi atau mencipta (C6). Hal ini dapat dijadikan acuan kelayakan RPP 1 lembar yang dikembangkan serta kevalitan UKBM dalam meningkatkan Higher Order Thinking Skill untuk digunakan sebagai media bahan ajar pada aktivitas pendidikan fisika di sekolah pada fokus materi suhu serta kalor.

\section{DAFTAR PUSTAKA}

Akbar, S. (2013). Instrumen Perangkat Pembelajaran. Remaja Rosdakarya.

Anderson, L. W., Krathwohl, D. R., \& Bloom, B. S. (2001). Revised Bloom's Taxonomy. In A Taxonomy for Learning, Teaching, and Assessing: A Revision of Bloom's Taxonomy of Educational Objectives.

Arends, R. (2008). Learning to Teach. Penerjemah: Helly Prajitno \& Sri Mulyani. McGraw Hill Company.

Barratt, C. (2014). Higher-Order Thinking Skill. Internasional Seminar on Current Issue In Primary Education. Prodi PGSD Universitas Muhammadiah Makar.

Bloom, B. S., Engelhart, M. D., Furst, E. J., Hill, W. H., \& Krathwohl, D. R. (1956). The Classification of Educational Goals. Taxonomy of Educational Objectives, 62-197.

Direktorat Pembinaan SMA. (2017). Pedoman penyelenggaraan sistem kredit semester (SKS) di SMA. 1-36.

Itsnawati, S., Budiyanto, M., \& Purnomo, A. R. (2019). Pensa E-Jurnal: Pendidikan Sains Validitas Lembar Kerja Peserta Didik Berbasis Higher Order Thinking Skills Dengan Tema Pencemaran Lingkungan Untuk. 7(3), 377-381.

Kemendikbud. (2017). Panduan Penilaian oleh Pendidikan dan Satuan Pendikin untuk Sekolah Menengah Atas. Direktorat Pembinaan Sekolah Menengah Atas Direktorat Jenderal Pendidikan dan Kebudayaan. $7694140(021), 7694140$.

Lestari, Y. (2017). Pengembangan Lembar Kegiatan Siswa (Lks) Berbasis Contextual Teaching and Learning (Ctl) Pada Materi Perubahan Lingkungan. BioEdu, 6(3), 250133.

Maghfiroh, R. A. (2020). Keterampilan Berpikir Kritis Dalam Unit Kegiatan Belajar Mandiri ( Ukbm ) Pembelajaran Sejarah Indonesia Kelas X Tahun Ajaran 2019/ 2020 Di Sman 1 Krembung. AVATARA, e-JournalPendidikanSejarah,8(1).

https://jurnalmahasiswa.unesa.ac.id/index.php/avatara/article/view/31858

McKenney, S., \& Reeves, T. C. (2014). Educational design research. Handbook of Research on Educational 
513 Validitas Unit Kegiatan Belajar Mandiri Untuk Meningkatkan Higher Order Thinking Skill Peserta Didik - Nurul Afifah, Dwikoranto

DOI: https://doi.org/10.31004/edukatif.v3i2.352

Communications and Technology: Fourth Edition, January 2013, 131-140. https://doi.org/10.1007/9781-4614-3185-5_11

Nugroho. (2018). HOTS - Kemampuan Berpikir Tingkat Tinggi: Konsep, Pembelajaran, Penilaian dan Soal soal. Gramedia Widisarana Indonesia.

Permendikbud. (2014). Penyelenggaraan Sistem Kredit Semester Pada Pendidikan Dasar Dan Pendidikan Menengah.

Permendikbud. (2016). Peraturan Menteri Pendidikan dan Kebudayaan nomor 24 tahun 2016 tentang kompetensi inti dan kompetensi dasar pelajaran pada Kurikulum 2013 pada pendidikan dasar dan pendidikan menengah. Peraturan Menteri Pendidikan Dan Kebudayaan, 2025, 5.

PSMA, D. (2017). Panduan Pengembangan Unit Kegiatan Belajar Mandiri (UKBM) @2017-Direktorat Pembinaan SMA.

Riduwan. (2015). Skala Pengukuran Variabel - Variabel Penilaian. Alfabeta.

Surosos, S. (2016). Analisis Kesalahan Siswa Dalam Mengerjakan Soal-Soal Fisika Termodinamika Pada Siswa Sma Negeri 1 Magetan. Jurnal Edukasi Matematika Dan Sains, 4(1), 8. https://doi.org/10.25273/jems.v4i1.200

Thiagarajan, S., D. S dan Semmel, M. I. (1976). Instructional development for training teachers of exceptional children: A sourcebook. Journal of School Psychology, 14(1), 75. https://doi.org/10.1016/00224405(76)90066-2

Trianto. (2009). Mendesain Model Pembelajaran Inovatif - Progresif. Kencana Prenada Media Group.

Widana, I. W. (2017). Modul penyusunan soal HOTS.

Widyastuti, R. (2015). Proses Berpikir Siswa Dalam Menyelesaikan Masalah Matematika Berdasarkan Teori Polya Ditinjau Dari Adversity Quotient Tipe Climber. Al-Jabar : Jurnal Pendidikan Matematika, 6(2), 183-194. https://doi.org/10.24042/ajpm.v6i2.48 